\title{
Does free public transit increase physical activity and independent mobility in children? Study protocol for comparing children's activity between two Finnish towns with and without free public transit
}

\author{
Arto J. Pesola ${ }^{1 *}$ (1), Pirjo Hakala ${ }^{1}$, Päivi Berg ${ }^{2}$, Samira Ramezani ${ }^{3}$, Karen Villanueva ${ }^{4}$, Sari Tuuva-Hongisto², \\ Jussi Ronkainen ${ }^{2}$ and Tiina E. Laatikainen
}

\begin{abstract}
Background: Children's habitual physical activity, including active travel and catching public transit (walking and cycling to and from destinations), and independent mobility (mobility without an adult) have decreased. Public transit trips are physically active and can provide access to hobbies independent of parents, but there is no devicemeasured data about children's total physical activity time following the introduction of free public transit. Our aim is to compare physical activity and independent mobility between children living in two Finnish towns, one with a recently introduced free public transit system, and the other without free public transit.

Methods: The city of Mikkeli has provided free public transit for all comprehensive school children since 2017. Various districts from Mikkeli, and the reference town of Kouvola (towns from South-Eastern Finland with a comparative population size and geographical structure), are selected based on their accessibility and the availability of public transit services. Samples of 10-12-year-old children will be recruited through primary schools. We will compare moderate-to-vigorous physical activity time, sitting time (a thigh-worn Fibion ${ }^{\circledR}$ device) and independent mobility (a participatory mapping method, PPGIS) of children: 1) who live in towns with and without free public transit, 2) who live and go to school in districts with high vs. low perceived and objective access to free public transit, and 3) who report using vs. not using free public transit. In addition, ethnography will be used to get insights on the social and cultural effects of the free public transit on children's and parent's everyday life.
\end{abstract}

(Continued on next page)

\footnotetext{
* Correspondence: arto.pesola@xamk.fi

${ }^{1}$ Active Life Lab, South-Eastern Finland University of Applied Sciences, Raviradantie 22b, 50100 Mikkeli, Finland

Full list of author information is available at the end of the article
}

(c) The Author(s). 2020 Open Access This article is licensed under a Creative Commons Attribution 4.0 International License, which permits use, sharing, adaptation, distribution and reproduction in any medium or format, as long as you give appropriate credit to the original author(s) and the source, provide a link to the Creative Commons licence, and indicate if changes were made. The images or other third party material in this article are included in the article's Creative Commons licence, unless indicated otherwise in a credit line to the material. If material is not included in the article's Creative Commons licence and your intended use is not permitted by statutory regulation or exceeds the permitted use, you will need to obtain permission directly from the copyright holder. To view a copy of this licence, visit http://creativecommons.org/licenses/by/4.0/ The Creative Commons Public Domain Dedication waiver (http://creativecommons.org/publicdomain/zero/1.0/) applies to the data made available in this article, unless otherwise stated in a credit line to the data. 
(Continued from previous page)

Discussion: There is a need for scalable solutions that can increase children's physical activity independent of their socioeconomic background or place of residence. This project will give information on how a political action to provide free public transit for children is associated with their total physical activity time and independent mobility patterns, therefore providing highly relevant information for political decision-making and for promoting independent physical activity in children.

Keywords: Children's independent mobility, Physical activity, Sedentary time, Moderate-to-vigorous physical activity, Accelerometer, SoftGIS, PPGIS, Ethnography, Public transport, Bus, Commuting, Built environment, Accessibility

\section{Background}

Active travel choices, such as walking and cycling to and from places, can form a significant proportion of children's daily physical activity time $[1,2]$. Active travel is a regular and frequent behavior that children can do independently. Despite this potential, children's independent and active travel and other unorganized forms of physical activities have decreased during the past decades [3-5]. In Finland, the number of schools has decreased by $27 \%$ between the years 2000-2011, and potentially due to longer school-travel distance the proportion of primary school children driven to school by their parents has increased from 16 to $20 \%$ [6-8]. A similar trend has occurred during leisure time as a consequence to increased number of children participating in organized sports and other hobbies [5]. Children's independent mobility (CIM) has decreased and replacement of independent active travel choices by private car is one of the main contributors to the total physical activity time decrement in children $[8,9]$. Therefore, supporting children's independent active travel is an important strategy in increasing their daily physical activity time.

Like active travel, public transit use is a regular, frequent and physically active behavior that children can do independently. Yet, public transit use is often ignored as being part of active travel choices. Public transit use has potential to increase total physical activity time through at least two logical mechanisms. Accessing public transit requires walking from the origin to the transit stop, and again to the destination of interest. A median transit-related activity time is $10-20 \mathrm{~min}$ in children, therefore forming a significant proportion of public transit users' daily activity $[10,11]$. Despite active travel as a means to increase CIM, there is a drastic drop in active transit in children living outside of a "comfort zone" distance (e.g. $5 \mathrm{~km}$ or more) from their places of interest $[2,12,13]$. CIM has decreased particularly in small towns and countryside, where the service network has little by little become sparser [9]. Therefore, public transit can benefit especially children who rarely travel actively, or whose mobility choices are restricted because of their socioeconomic background or distance to their places of interest. The second mechanism how public transit use can increase total physical activity is increasing children's accessibility of leisure time activities independently [14]. Participation in organized sports and exercise can depend on the accessibility of the specific facilities, car ownership and household income, which undermines children from a low socioeconomic position [15, 16].

Despite public transit use increases physical activity during single journeys, little data exists on the effects of free public transit introduction on children's whole day physical activity time. Public transit use is positively associated with the whole day physical activity time and the odds of meeting the physical activity recommendations in adults [17, 18]. Children using public transit for school journeys accumulate significantly more device-measured moderate-tovigorous physical activity time (MVPA) during the whole day compared with both active commuters and those driven to school by their parents [19]. Despite this support for the use of public transit as an important source of the whole day physical activity, it remains unclear if these benefits are amplified by public transit use outside of school hours and following introduction of free public transit policies. Introduction of free bus travel has increased the odds of use in both the young and older people [20, 21]. Moreover, free public transit policy is associated with increased physical activity level and reduced obesity incidence in older adults [21, 22]. Under 18-year-old Londoners were provided free bus travel from 2006, which led to replacing some proportion of short walking trips $(<1 \mathrm{~km})$ with bus travelling $[23,24]$. However, there was no evidence of decreased total walking time or total active travel time, whereas the number of car trips and distance traveled by car decreased [23, 24]. Moreover, there was qualitative evidence of an increased independent mobility level and a sense of social inclusion for children [24]. It is noteworthy that in this study children's physical activity and sedentary time were assessed by surveys, independent mobility was assessed from a subgroup, and the findings are restricted to a highly urbanized area where children already enjoy a higher degree of CIM [9]. To rigorously evaluate the benefits public transit provides for children, it is important to measure children's independent mobility and objectively assess habitual physical activity during the whole day as a 
consequence of increased public transit accessibility and/or use in areas where children may have restrictions in their independent mobility, like in small towns and rural areas.

The idea for this study arouse from current policy-debate and the city of Mikkeli's decision of providing free public transit for all primary and secondary school children for the whole day. Advocates have supported the decision by commenting that the free public transit would decrease the need for extra school transportation services, replace parent's chauffeur services and increase equality of access to hobbies during leisure time, ultimately leading to increased total physical activity. Others have criticized the decision by pointing out that free public transit would replace children's active commuting by bike and foot. The aim of this study is to investigate the effects of free public transit provision on the objectively measured physical activity of 10 to 12-year-old children. In addition, we will investigate this effect at different levels of the socio-ecological model, including individual, sociocultural and physical environment levels [25]. We hypothesize that children living in Mikkeli where free public transit is available have more MVPA during school time (including commuting to school) and on leisure time and weekends (improved access to hobbies and a more mobile way of living) compared with their peers living in Kouvola without free public transit. We also hypothesize that children living in Mikkeli have a lower sitting time and a higher degree of CIM due to free public transit. In this paper, we report study design and methods, and for recruitment design purposes, report spatial and public transit service-based accessibility data on Mikkeli and Kouvola regions, Finland.

\section{Design and methods}

The Finnish Basic Education Act guarantees free transportation to all pupils whose school journey is five kilometers or more. In 2017, the city of Mikkeli made a political decision to provide free public transit for all primary and secondary school children for the whole day. FREERIDE is a cross-sectional study comparing physical activity and independent mobility levels in a sample of 10 to 12-year-old children living in Mikkeli as compared to children living in Kouvola, a reference town without free public transit. Mikkeli (54,000 residents) and Kouvola (83,000 residents) are small towns located in SouthEastern Finland and have a similar climate, geographical structure and possibilities for active transit, including an active bus network for local traffic. Children are being recruited through primary schools located in neighbourhoods that are paired between the towns based on objectively analysed public transit accessibility.

\section{Primary outcome}

The primary outcome is device-measured MVPA (minutes per day) assessed as a daily average of a seven-day measurement period and compared between children living in Mikkeli and Kouvola. Minimum difference of interest (MDI) is $15 \mathrm{~min} /$ day of MVPA. We expect a $6 \%$ $(\rho=0.06)$ school-level intraclass-correlation and assume average $n$ per cluster of 20 (design effect $=2.1$ estimated with formula $1+(n-1) \rho)$. A sample size of 200 for each town spread across 10 clusters is required to have $\geq 80 \%$ power to detect MDI at 5\% alpha error level (two-tailed significance).

\section{Secondary outcomes}

Our secondary outcomes are device-measured sitting time and CIM compared between children living in Mikkeli and Kouvola. CIM will be assessed with a Public Participatory GIS (PPGIS) questionnaires, which both the participating children and their parents will answer (child PPGIS questionnaire and parent PPGIS questionnaire).

\section{Mechanisms}

In addition to the town-level comparisons, we will compare MVPA, sitting time and CIM between children having a subjectively and objectively better versus worse access of public transit (neighbourhood level effects), as well as between children using versus not using public transit (individual level effects). We expect to see benefits from public transit use on MVPA and sitting time during school commuting [19], commuting to leisure destinations, and as a consequence of better accessibility of hobbies during weekdays and weekends [15] (domain level effects). Moreover, we will investigate the degree to which travel cost (free vs. non-free) influences children's travel mode choice (or CIM) and their MVPA while considering the effect of other latent (e.g. children's perceptions of safety and security, children's perception of transit accessibility, parent's perceptions of safety and security, parents' perceptions of transit accessibility and of degree of environmental accountability) and objective (e.g. objective accessibility measures) factors. We will also conduct a qualitative ethnographic study to investigate social and cultural interpretations of free public transit from the perspective of children and their families. The ethnographic study will be conducted with 6-12 families living in Mikkeli and Kouvola areas differing in their public transit accessibility (1-2 families from clusters 1-6, 12 families from clusters $7-8$ and 1-2 families from clusters 9-10 per town).

\section{Neighborhood and school selection}

In order to create comparable school pairs for the study, we conducted analysis for school pairings. Thus, multiple public transit accessibility measures for each school were assessed. This was done after determining the sample size but prior to contacting schools, participant recruitment and data collection. 
Most studies on public transit accessibility focus on assessing proximity to public transit stop or number of available public transit stops in a given area [26-29]. However, to ensure that the public transit accessibility measures in this study are sensitive enough to create school pairings, additional accessibility measures for each school were calculated. First, each school was categorized based on their allocated urban zone. This was done by using the YKR Urban Zones dataset provided by the Finnish Environment Institute (SYKE). YKR Urban Zones data is a $250 \mathrm{~m} \times 250 \mathrm{~m}$ grid-based dataset in which all city regions in Finland are divided into different zones based on three main criteria: distance to the city center, public transit frequency and walking distance to public transit stops. Furthermore, these criteria are calculated for each YKR grid cell which is then assigned a value indicating if it belongs to walking, public transit or car zone [30]. For our study, each school was assigned with an YKR urban zone based on the YKR grid they are within.

In addition to determining which YKR zones each school belongs to, a 1000-m network buffer service area for each school was created and public transit accessibility within each of these service areas was assessed. Buffers of 400 to $600 \mathrm{~m}$ are commonly used measures in public transit and urban planning field to identify the area from which most transit users access the system by foot $[28,31]$. For this study the network distance for each school was increased to $1000 \mathrm{~m}$, as residents' willingness to walk to public transit stop can be much higher [31, 32], especially in lower-density areas [33]. Moreover, some of the schools did not have any public transit stops within an 800-m network distance buffer which confirmed the need for increased buffer size.

Public transit accessibility was assessed within the 1000-m school network buffer. The total number of public transit stops and public transit stop density value (number of stops / service area $\mathrm{m} 2$ ) for each school was calculated. In addition, we also created measures of public transit service level for each school using transit timetable data from both cities [28]. For each public transit stop we assigned a frequency value representing the number of trips through the stop during 1 day. In addition, we calculated the street network distance from each school to the city center (main railway station). Finally, a school public transit accessibility dataset was created including all schools from both cities with measures indicating which city the school belongs to, the YKR Urban Zone of the school, frequency and density of public transit stops within $1000 \mathrm{~m}$ network buffer around the school, total and average number of trips per day and per hour within $1000 \mathrm{~m}$ network buffer around the school and total and average number of trips during commuting and non-commuting hours within the 1000 $\mathrm{m}$ network buffer. Finally, we created 10 school pairs to reach a sample size of 200 children for each town spread across 10 clusters (schools) (Table 1).

\section{School and participant recruitment}

Based on the objectively assessed public transport accessibility (Table 1 and Fig. 1) participating children will be recruited through paired primary schools across Mikkeli and Kouvola. We have received permission to contact schools from the head of local education and culture department of both towns. The recruitment of schools will be done in three stages: 1) contacting the principals and 4th and 5th grade teachers of schools 2) a short oral presentation about study protocol given by researcher 3 ) a participation agreement from the principals of the schools.

We will recruit and measure the paired schools from the Mikkeli and Kouvola simultaneously (e.g. measurements are started in Mikkeli on Monday and in Kouvola on Tuesday). We aim to measure one 4th grade and one 5th grade class per school, with the aim to recruit a minimum of 20 children per school. A researcher will send via email or deliver personally an information letter and an informed consent to the teachers, who will deliver them to parents/guardians via children. Children's participation in the data collection will be voluntary and they are required to return the consent form signed by their parents before taking part in the measurements. Parents will declare their participation in the same form.

The recruitment is scheduled to start in February 2020 and the first measurements in March 2020. The measurements will be conducted during snow-free time.

\section{Measurement protocol}

The measurement protocol per school requires two visits by the researcher. The researcher will send informed consent forms to the school before the first visit. The children are asked to return the written informed consent for the first researcher visit. At the first visit, the children will complete the child PPGIS questionnaire in the computer class of the school under the researcher supervision. Because of the questionnaire nature, it can be integrated into Environmental Education or Biology lessons. The lesson will be agreed with the responsible teacher beforehand. The researcher will measure height and weight, provide the accelerometer and give instructions for the physical activity measurements and completing the PPGIS mobility $\log$ on one child at a time during the first visit. The children will be asked to continue their normal daily life as they usually do, while filling in the $\log$ and wearing the accelerometer for 8 days. They will be asked to return the accelerometer to the teacher after the measurement period and the researcher collects the devices at the second visit. A website link to the parent PPGIS questionnaire will be sent to the parents/guardians via e-mail after their children's 8 days 
Table 1 Objective public transit (PT) accessibility measures of each school in Mikkeli and Kouvola and school pairs of the study

\begin{tabular}{|c|c|c|c|c|c|c|c|c|c|c|c|c|c|}
\hline $\begin{array}{l}\text { Pair } \\
\text { nr. }\end{array}$ & City & $\begin{array}{l}\text { School } \\
\text { id }\end{array}$ & $\begin{array}{l}\text { YKR } \\
\text { zone }^{a}\end{array}$ & $\begin{array}{l}\text { PT stop density } \\
\text { (PT stops per } \\
\text { school network } \\
\text { area) }\end{array}$ & $\begin{array}{l}\text { PT } \\
\text { trips } \\
\text { per } \\
\text { day }\end{array}$ & $\begin{array}{l}\text { Average } \\
\text { PT trips } \\
\text { per day }\end{array}$ & $\begin{array}{l}\text { Daily PT trips } \\
\text { per school } \\
\text { network area }\end{array}$ & $\begin{array}{l}\text { PT } \\
\text { trips } \\
\text { per } \\
\text { hour }\end{array}$ & $\begin{array}{l}\text { Hourly PT } \\
\text { trips per } \\
\text { school } \\
\text { network area }\end{array}$ & $\begin{array}{l}\text { PT trips } \\
\text { 07-10 am }\end{array}$ & $\begin{array}{l}\text { Average } \\
\text { PT trips } \\
07-10 \mathrm{am}\end{array}$ & $\begin{array}{l}\text { PT trips } \\
\text { on } \\
\text { weekdays }\end{array}$ & $\begin{array}{l}\text { Average } \\
\text { PT trips } \\
\text { per } \\
\text { weekdays }\end{array}$ \\
\hline \multirow[t]{2}{*}{1} & Mikkeli & 1007 & 2 & 15 & 910 & 51 & 555 & 38 & 23 & 181 & 10 & 500 & 28 \\
\hline & Kouvola & 2011 & & 10 & 344 & 31 & 268 & 14 & 11 & 65 & 6 & 172 & 16 \\
\hline \multirow[t]{2}{*}{2} & Mikkeli & 1010 & 41 & 18 & 1646 & 57 & 998 & 69 & 42 & 281 & 10 & 784 & 27 \\
\hline & Kouvola & 2023 & & 14 & 1190 & 70 & 734 & 50 & 31 & 253 & 15 & 607 & 36 \\
\hline \multirow[t]{2}{*}{3} & Mikkeli & 1012 & 5 & 10 & 674 & 48 & 478 & 28 & 20 & 80 & 6 & 300 & 21 \\
\hline & Kouvola & 2029 & & 9 & 544 & 49 & 429 & 23 & 18 & 110 & 10 & 290 & 26 \\
\hline \multirow[t]{2}{*}{4} & Mikkeli & 1013 & 5 & 8 & 400 & 40 & 313 & 17 & 13 & 51 & 5 & 163 & 16 \\
\hline & Kouvola & 2007 & & 6 & 418 & 60 & 331 & 17 & 14 & 99 & 14 & 264 & 38 \\
\hline \multirow[t]{2}{*}{5} & Mikkeli & 1016 & 5 & 7 & 52 & 9 & 55 & 2 & 2 & 23 & 4 & 52 & 9 \\
\hline & Kouvola & 2000 & & 4 & 107 & 27 & 75 & 4 & 3 & 24 & 6 & 64 & 16 \\
\hline \multirow[t]{2}{*}{6} & Mikkeli & 1006 & 5 & 12 & 249 & 16 & 182 & 10 & 8 & 50 & 3 & 138 & 9 \\
\hline & Kouvola & 2006 & & 6 & 93 & 16 & 98 & 4 & 4 & 12 & 2 & 93 & 16 \\
\hline \multirow[t]{2}{*}{7} & Mikkeli & 1003 & 5 & 8 & 689 & 57 & 420 & 29 & 18 & 119 & 10 & 356 & 30 \\
\hline & Kouvola & 2026 & & 5 & 364 & 46 & 230 & 15 & 10 & 66 & 8 & 158 & 20 \\
\hline \multirow[t]{2}{*}{8} & Mikkeli & 1018 & 0 & 12 & 172 & 11 & 123 & 7 & 5 & 52 & 3 & 117 & 8 \\
\hline & Kouvola & 2022 & & 7 & 92 & 9 & 65 & 4 & 3 & 27 & 3 & 92 & 9 \\
\hline \multirow[t]{2}{*}{9} & Mikkeli & 1005 & 0 & 9 & 117 & 17 & 78 & 5 & 3 & 23 & 3 & 100 & 14 \\
\hline & Kouvola & 2033 & & 7 & 169 & 19 & 127 & 7 & 5 & 45 & 5 & 121 & 13 \\
\hline \multirow[t]{2}{*}{10} & Mikkeli & 1022 & 0 & 8 & 221 & 18 & 149 & 9 & 6 & 71 & 6 & 162 & 14 \\
\hline & Kouvola & 2031 & & 8 & 314 & 31 & 252 & 13 & 11 & 90 & 9 & 174 & 17 \\
\hline
\end{tabular}

a $2=$ walking zone, $41=$ intensive public transit zone, $5=$ car zone, $0=$ out of urban zones

measurement period. The parents' email address will be obtained from their informed consent.

\section{Measurements}

\section{Accelerometer}

Children will wear a Fibion ${ }^{\curvearrowleft}$ device $(20 \mathrm{~g}, \mathrm{~L}=30 \mathrm{~mm}, \mathrm{~W}=$ 32 mm, T = 10 mm; Fibion Inc., Jyväskylä, Finland) for 8 days,

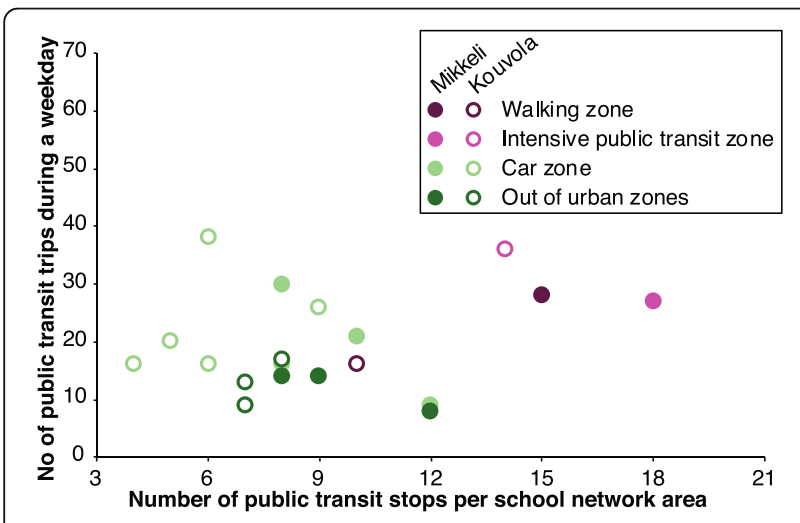

Fig. 1 Average number of public transit trips during weekdays as a function of public transit stop number across the Mikkeli and Kouvola YKR zones
$24 \mathrm{~h}$ per day. At day one, the measurement will be started during the school day and the following full 7 days will be utilized for analysis. The Fibion ${ }^{\oplus}$ device will be attached on the participant's right thigh. The device will be positioned vertically at the centerline and horizontally at the upper third level on the anterior side of the thigh and secured in a waterproof covering with medical adhesive tape. The Fibion ${ }^{\bullet}$ device measures raw acceleration on three axes with an internal sampling rate of $12.5 \mathrm{~Hz}$. The Fibion ${ }^{\oplus}$ device has no buttons or display and can operate for around 30 days on full charge condition. Fibion $^{\odot}$ is valid in detecting sitting and continuous uninterrupted sitting periods against direct observation, and light physical activity, MVPA and total energy expenditure against indirect calorimetry [21]. Moreover, Fibion ${ }^{\circledR}$ gives estimates of activity types including standing (mean difference 17,2 min/12 $\mathrm{h}$ day, limits of agreement (LoA) $-12,9$ to $47,3 \mathrm{~min}$ ), walking (mean difference $-17,3 \mathrm{~min} / 12 \mathrm{~h}$ day, LoA $-47,4$ to $12,8 \mathrm{~min}$ ) and cycling duration (mean difference $-6,8 \mathrm{~min} / 12 \mathrm{~h}$ day, LoA $-18,7$ to $5,0 \mathrm{~min}$ ) [34]. Fibion ${ }^{\bullet}$ has been used to monitor children's daily activity previously [35].

\section{PPGIS}

PPGIS (also referred to as SoftGIS) is an online method developed to integrate the human behavior, preferences, 
experiences and ideas to actual physical settings and to the datasets of GIS system [36, 37]. SoftGIS methodology relies on collecting, analyzing, and delivering soft, geocoded knowledge produced by respondents. PPGIS methods enable a unique collection of large data sets producing scientifically high quality spatial research knowledge and findings, which have been shown to be easy to translate to practical knowledge and proposals for action [38]. In this study, children will keep a PPGIS mobility $\log$ on their mobile phone or desktop computer web browser, where they map their school, hobbies and other destinations, time spent at and travel mode to destinations during the seven-day accelerometer measurement period. Children will also report sleep times (light out to waking up) and any accelerometer removal periods or other abnormal occasions that may affect the measurement. With the mapped elements a spatial activity space for each child can be delineated [39]. In addition to spatial elements, the child PPGIS questionnaire filled in school includes questions of children's independent mobility [40], self-assessed PA (Short-form international physical activity questionnaire, IPAQ), subjective accessibility of (free) public transport [41], children's usage of (free) public transport, perceived health and parental support for children's physical activity [42]. The parent PPGIS questionnaire includes questions regarding their children's mobility licenses [40] as well as self-assessed PA (IPAQ), subjective accessibility of public transport [41], own usage of public transportation and private car and finally their environmental attitudes and socioeconomic status of family.

The PPGIS questionnaire will be supplemented with actual GPS recordings (Sensedoc ${ }^{\text {Th }}$ 2.0; MAX-M8 Global Navigation Satellite System receiver from u-blox, $2 \mathrm{~s}$ epoch, Tri-axial accelerometer, $50 \mathrm{~Hz}$ ) with a minimum of 30 children per town. The GPS data is collected to compare and validate how the PPGIS data about children's' activity spaces match with the GPS tracks and accelerometer data collected from each participating child. The children participating in the testing phase will wear GPS devices for two consecutive days and answer the PPGIS survey post-GPS measurement. GPS devices with built in accelerometers are big and expensive devices. Moreover, GPS data collection and analysis is highly resource demanding. Thus, as part of this research project we want to study the potentials of combining resource modest PPGIS surveys and easy-to-wear accelerometer devices for comprehensive objective and subjective spatially referenced physical activity data collection.

\section{Ethnography}

The aim of the ethnographic study is to understand the social and cultural effects and mechanisms of the free bus experiments in children's and parent's everyday life.
The everyday mobility shapes and structures the family life and the children's individual mobility is at the core of the family-relations: it is the arena of intertwining restrictions, fears, attitudes and recommendations. The ethnographic study provides understandings and a thick description [43] of the broader everyday mobility patterns [44], the social and cultural contexts were the free public transit intervenes $[45,46]$.

Ethnography refers to the description of cultural systems or an aspect of culture based on fieldwork in which the investigator is immersed in the ongoing everyday activities of the designated community for the purpose of describing the social context, relationships and processes relevant to the topic. At the core is the fieldwork, which includes field note, in-depth interviews, guided-tourinterviews and observations.

\section{Outcomes}

MVPA, light activity, sitting, standing, walking and cycling time will be assessed with the Fibion ${ }^{\circ}$ device as a daily average of a seven-day measurement period, and separately for travel time, school time, non-school time and hobbies. Fibion uses device orientation and impact data to estimate these postures and activity classes. Data from the Fibion ${ }^{\circ}$ devices will be uploaded from the device to the manufacturer's web-browser-based online service and the participants' weight, height, age, and sex will be submitted to the service. The service analyses the data and provides day-by-day and minute-by-minute results for each activity class duration (in seconds) and energy expenditure (in METs) in a CSV format. The Fibion $^{\circ}$ service automatically analyses non-wear time as $>30$ min periods when the device remains still. MVPA is analyzed by summing the duration of all activities with energy expenditure above 3 METs. The PPGIS mobility $\log$ is synced with the CSV data timeline to remove sleep time and to analyze domain-specific results. Any days with less than $10 \mathrm{~h}$ of wear-time, and any measurements with less than 4 valid days and/or those with zero weekend days, will be excluded from the analysis [47]. The final results are normalized to $16 \mathrm{~h}$ waking time and weighted between weekdays (weight 5/7) and weekend days (weight 2/7).

Children's independent mobility (CIM). CIM will be operationalized on two levels: as a set of mobility licenses parents give to their children (parent and child PPGIS questionnaires) and as the actual mobility patterns of children according to the original CIM survey by Hillman et al. 1990 [40] (child PPGIS questionnaire).

Mobility licenses. In the child PPGIS questionnaire children will be answering questions regarding the mobility license granted to them by their parents $[9,40]$. Both children and parents will be asked whether the child is allowed to cross main roads alone, travel home 
from school alone, and travel on buses alone. Children will also answer if they are allowed to cycle on main roads alone. In the parent PPGIS questionnaire, respectively, in addition to the three previously mentioned question, the parents will report if their child can go on their own to places other than school or to go out alone after dark. The mobility license questions will be answered using a dichotomous scale $(0=$ no, $1=$ yes $)$. A mobility license score will be calculated as a sum of aforementioned six items as according to the original study by Hillman and colleagues (1990).

Mobility patterns. Children's actual independent mobility patterns will be studied with child PPGIS questionnaire. Children will be asked about their independent mobility to and from school and other destinations on the day they answer the child PPGIS questionnaire at school and on a typical day. Dichotomous variables are created from the answers as $1=$ travelled without adults or older children during both journeys (travelled "on my own" or "with child/children of same age or younger") and $0=$ travelled with adults/older children (travelled with "parent," "another adult," or "older child/teenager") [9]. A mode value will be created and used to determine children's actual independent mobility. Second, children will answer questions about their school and other travel modes. Travel mode choice will be surveyed as walking, bicycle, public transit, car, school shuttle bus, skating or scooting or other mode of transport. The school travel mode will be constructed into a dichotomous variable but differing from the original CIM research [33], we will include public transit as an active mode of transportation (walking, bicycle, public transit) and include car and school bus as inactive modes.

Use of public transit on a typical week will be assessed based on the travel mode choices children and adults map in the child and adult PPGIS questionnaires. During the accelerometer measurement week children will map their actual travel mode choices, including use of public transit, in the PPGIS mobility log.

Subjective public transit accessibility will be assessed in the child and parent PPGIS questionnaire based on Lättman et al. 2016 [41]. The participants are asked to evaluate their perceived public transit accessibility on a 7-point Likert scale on four different measures; It is easy to do (daily) activities with public transport, If public transport was my only mode of travel, I would be able to continue living the way I want, It is possible to do the activities I prefer with public transport and Access to my preferred activities is satisfying with public transport.

The experienced implications of free public transit to everyday well-being and equality will be assessed through guided-tour-interviews and observations, field notes in the ethnography study. How free bus rides shape the habits and routines of the children's and parent's everyday mobility and lifestyles will be studied with indepth- interviews with the families in the ethnography study. Finally, how families argue the necessities or restrictions of CIM (health and well-being, freedom, security, socio-economic, ecological dimensions) will be studied with in-depth-interviews with the families, as well as through observations and field notes.

\section{Statistical analysis}

Accessibility measures were compared with T-tests with Bonferroni corrections $\left(\alpha_{\text {altered }}=.05 / 12\right)$ between schools of Mikkeli and Kouvola to determine if they are comparable to each other and to create comparable school pairs that do not differ from each other statistically significantly. Ten accessibility measures (Table 1) were selected for further analysis for school pairing as they did not show statistically significant differences between the schools. The primary and secondary outcomes will be compared between towns using a hierarchically nested fixed effects ANOVA, where the children will be nested within the cluster factor and compared between the fixed town factor. To study the mechanisms, the models are extended with neighborhood (subjective and objective public transit accessibility), individual (actual use of public transit), as well as domain level factors (public transit use for school commuting and commuting to leisure destinations), respectively. Moreover, we will compare MVPA and sitting time during travel time, school time, non-school time and hobbies, with the same design. The mechanisms will be further studied with structural equation modelling and/or advanced discrete choice modelling (e.g. Integrated choice and latent variable models) in order to study the influence of travel cost (free/not free) on travel mode choice, MVPA and CIM while considering the effect of other latent (e.g. children's perceptions of safety and security, children's perception of transit accessibility, parent's perceptions of safety and security, parents' perceptions of transit accessibility and of degree of environmental accountability) and objective (e.g. objective accessibility measures) factors.

\section{Discussion}

Integrating physical activity interventions into public policy, like transportation and city planning, is a way to shift physical activity level of societies [48]. The Finnish Basic Education Act guarantees free public transit for long $(\geq 5$ $\mathrm{km}$ ) school journeys. In 2017, city of Mikkeli extended this public service for all children and for the whole day, throughout the year. The purpose of this study is to measure how free public transit affects children's physical activity time as compared to children living in a reference town without such a service. In addition, children's independent mobility and sitting time will be studied between the two cities. This study will extend the current evidence base in many ways. We will use novel device-based activity 
monitoring, which will enable capturing transit-related and non-transit-related MVPA and sitting patterns during the whole day of children. Despite such benefits being reported in adults, the data in children is limited to measured school transit-related physical activity time, or selfreported total walking time [10, 11, 19, 23, 24]. Because the children will wear the activity monitor on their thigh, we will be able to measure time spent standing and cycling, which are inappropriately captured by waist-worn devices, but may be important physical activity modes for both active and public transit users. The interactive mapping technology (PPGIS) is used to capture both children's and parent's places of interest as well as their independent and dependent mobility patterns. This detailed mobility data will help us understand how free public transit shapes the families everyday life mobility. Finally, we will use ethnography to get insights on the social and cultural effects and mechanisms of the free public transit in children's and parent's everyday life. We believe this mixed methods approach will enable us to identify both the perceived and measured effects at the individual, family, school district, as well as the town levels.

A socio-ecological model of health behavior suggests that interventions should not focus only on intrapersonal factors, but also on the interrelationship between the individuals and their social, physical and policy environment $[49,50]$. However, reviews on physical activity interventions in children point out that the majority of evidence is from interventions focusing only to the intrapersonal and social factors, and that their effectiveness is typically small $[51,52]$. Moreover, limited evidence exists on the mediating and moderating mechanisms that could enlighten the reasons why the intervention effectiveness remain low [51]. For example, degree of independence [53], autonomy-supportive climate [54], the support of physical environment on walking and cycling [36] or access to facilities [15] are associated with increased physical activity. Research that focuses simply on the individual or social influences on physical activity have been criticized for failing to acknowledge the environment as well as the policy context where the behavior actually takes place [25]. The present setup and a combination of participatory mapping technology with device-measured physical activity enables us to model the effects at different levels of the socioecological model, including the policy-level. We will compare device-measured physical activity and CIM at the levels of political action (free vs. non-free public transit), neighborhood (objective public transit accessibility), family (CIM and parental support for physical activity) and individual level (subjective public transit accessibility, actual use of public transit and CIM).

To assist recruitment design, in this paper we report public transit accessibility in different Mikkeli and Kouvola regions. This accessibility data is interesting already on its own. The bus stop density and number of trips decreases considerably in car and out of urban zones, as compared to the urban zone. This accessibility difference may have a significant impact on the public transit use, as well as the potentially ensuing MVPA and CIM benefits, but this has not been fully considered in the previous studies. In addition, we will assess perceived public transit accessibility at children's' home environment, which will further enrich the accessibility data from the child's perspective. We will test these potential mechanisms in the secondary analyses as outlined before.

Independent physical activity improves health at childhood and provides an important foundation for lifelong physical activity and travel habits. This study will provide information about effects of a political action, provision of free public transit for all children, on the children's physical activity and independent mobility patterns. These results will assist public health, transportation and land use planning policy makers to consider how their decisions will affect children's physical activity habits.

\section{Abbreviations}

CIM: Children's independent mobility; IPAQ: International physical activity questionnaire; LoA: Limits of agreement; MDI: Minimum difference of interest; MVPA: Moderate-to-vigorous physical activity time; PPGIS: Public participation geographic information system; PT: Public transit

\section{Acknowledgements}

We would like to acknowledge Professor Marketta Kyttä, PhD, for her valuable support in study design and methodology.

\section{Authors' contributions}

AJP, TEL, ST-H and JR designed and wrote the original proposal. PH, PB, SR and KV participated in concept and design refinement. TEL did the analyses. AJP and TEL drafted the manuscript. All authors critically revised the manuscript and approved the final version.

\section{Funding}

Ministry of Education and Culture (OKM/30/626/2019). The funding body had no role in the design of the study and collection, analysis, and interpretation of data and in writing the manuscript.

\section{Availability of data and materials}

The datasets generated and/or analysed during the current study are available in the Traficom repository, http://developer.matka.fi/pages/en/ waltti-data.php

\section{Ethics approval and consent to participate}

The study protocol has been approved by Aalto University Research Ethics Committee (10th October 2019). All procedures follow European Union General Data Protection Regulation (2016/679), Finnish legislation on Personal Data Act (22.4.1999/523) and the UN Convention of the Rights of the Child. All research activities will follow good scientific practices according to the updated guidelines of the National Advisory Board on Research Integrity in Finland. Permission to recruit from schools will be asked from the responsible authorities and school principals. Children will be recruited on a voluntary basis by delivering a study briefing to parents through the schools. The children and their parents/legal guardians will be given truthful and realistic information on the procedures involved in the studies. Children will be asked for oral consent and their legal guardians will be asked to provide informed written consent. Study procedures, risks and benefits, as well as the voluntary nature of the study, are explained in the consent form. Parents and children have the right to withdraw from the study at any time without giving reason, and without enduring any consequences. 


\section{Consent for publication}

Not applicable.

\section{Competing interests}

AJP is a partner in Fibion Inc., a company that delivers the Fibion ${ }^{\circledR}$ devices used in this study. No funding was provided to this study by Fibion Inc. The remaining authors have declared that no competing interests exist.

\section{Author details}

Active Life Lab, South-Eastern Finland University of Applied Sciences,

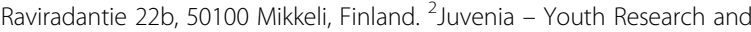
Development Centre, South-Eastern Finland University of Applied Sciences, Mikkeli, Finland. ${ }^{3}$ Department of Built Environment, Aalto University, Espoo, Finland. ${ }^{4}$ Centre for Urban Research, School of Global Urban and Social Studies, RMIT University, Melbourne, Victoria 3000, Australia.

\section{Received: 13 February 2020 Accepted: 20 February 2020} Published online: 17 March 2020

\section{References}

1. Larouche R, Saunders TJ, John Faulkner GE, Colley R, Tremblay M. Associations between active school transport and physical activity, body composition, and cardiovascular fitness: a systematic review of 68 studies. J Phys Act Health. 2014;11(1):206-27.

2. Kallio J, Turpeinen S, Hakonen H, Tammelin T. Active commuting to schoo in Finland, the potential for physical activity increase in different seasons. Int J Circumpolar Health. 2016;75(1):33319.

3. Dollman J, Norton K, Norton L. Evidence for secular trends in children's physical activity behaviour. Br J Sports Med. 2005;39(12):892-7.

4. Ekelund U, Tomkinson G, Armstrong N. What proportion of youth are physically active? Measurement issues, levels and recent time trends. $\mathrm{Br}$ J Sports Med. 2011:45(11):859-65.

5. Laakso L, Telama R, Nupponen H, Rimpelä A, Pere L. Trends in leisure time physical activity among young people in Finland, 1977-2007. Eur Phys Educ Rev. 2008;14(2):139-55.

6. Turpeinen $\mathrm{S}$, Lakanen $\mathrm{L}$, Hakonen $\mathrm{H}$, Havas $\mathrm{E}$, Tammelin T. Matkalla kouluun. Peruskoululaisten koulumatkat ja aktiivisten kulkutapojen edistäminen. Liikunnan. Liikunnan ja kansanterveyden edistämissäätiö LIKES; 2013.

7. Mehtäläinen J, Jokinen H, Välijärvi J. Kuntarakenne muutoksessa - entä koulutuspalvelut? Loppurapor. Helsinki: Jyväskylän yliopisto ja Suomen Kuntaliitto: 2013.

8. Fyhri A, Hjorthol R, Mackett RL, Fotel TN, Kyttä M. Children's active travel and independent mobility in four countries: development, social contributing trends and measures. Transp Policy. 2011;18(5):703-10.

9. Kyttä M, Hirvonen J, Rudner J, Pirjola I, Laatikainen T. The last free-range children? Children's independent mobility in Finland in the 1990s and 2010s. J Transp Geogr. 2015:47:1-12.

10. Durand CP, Pettee Gabriel KK, Hoelscher DM, Kohl HW III. Transit use by children and adolescents: an overlooked source of and opportunity for physical activity? J Phys Act Health. 2016;13(8):861-6.

11. Voss C, Winters M, Frazer A, McKay H. School-travel by public transit: rethinking active transportation. Prev Med Reports. 2015;2(December):65-70.

12. Børrestad $L A B$, Andersen $L B$, Bere E. Seasonal and socio-demographic determinants of school commuting. Prev Med (Baltim). 2011;52(2):133-5.

13. Fyhri A, Hjorthol R. Children's independent mobility to school, friends and leisure activities. J Transp Geogr. 2009;17(5):377-84

14. Palm M, Farber $\mathrm{S}$. The role of public transit in school choice and afterschool activity participation among Toronto high school students. Trave Behav Soc. 2020;19(August 2019):219-30.

15. Sallis JF, Prochaska JJ, Taylor WC. A review of correlates of physical activity. Med Sci Sport Exerc. 2000;32(5):963-75.

16. Brockman R, Jago R, Fox KR, Thompson JL, Cartwright K, Page AS. "Get off the sofa and go and play": Family and socioeconomic influences on the physical activity of 10-11 year old children. BMC Public Health. 2009;9:3-9.

17. Rissel C, Curac N, Greenaway M, Bauman A. Physical activity associated with public transport use-a review and modelling of potential benefits. Int J Environ Res Public Health. 2012;9(7):2454-78.

18. Villanueva K, Giles-Corti B, McCormack G. Achieving 10,000 steps: a comparison of public transport users and drivers in a university setting. Prev Med (Baltim). 2008:47(3):338-41.
19. Owen CG, Nightingale CM, Rudnicka AR, van Sluijs EMF, Ekelund U, Cook DG, et al. Travel to School and Physical Activity Levels in 9-10 Year-Old UK Children of Different Ethnic Origin; Child Heart and Health Study in England (CHASE). von Elm E, editor. PLoS One. 2012;7(2):e30932.

20. McDonald N, Librera S, Deakin E. Free transit for low-income youth: experience in San Francisco Bay Area, California. Transp Res Rec J Transp Res Board. 2004;1887(1):153-60

21. Webb E, Netuveli G, Millett C. Free bus passes, use of public transport and obesity among older people in England. J Epidemiol Community Health. 2012;66(2):176-80

22. Laverty AA, Webb E, Vamos EP, Millett C. Associations of increases in public transport use with physical activity and adiposity in older adults. Int J Behav Nutr Phys Act. 2018:15(1):1-10

23. Edwards P, Steinbach R, Green J, Petticrew M, Goodman A, Jones A, et al. Health impacts of free bus travel for young people: evaluation of a natura experiment in London. J Epidemiol Community Health. 2013;67(8):641-7.

24. Green J, Steinbach R, Jones A, Edwards P, Kelly C, Nellthorp J, et al. On the buses: a mixed-method evaluation of the impact of free bus travel for young people on the public health. Public Heal Res. 2014;2(1):1-206.

25. Sallis JF, Cervero RB, Ascher W, Henderson KA, Kraft MK, Kerr J. An ecological approach to creating active living communities. Annu Rev Public Health. 2006;27(1):297-322.

26. Biba S, Curtin KM, Manca G. A new method for determining the population with walking access to transit. Int J Geogr Inf Sci. 2010;24(3):347-64.

27. Currie G. Quantifying spatial gaps in public transport supply based on social needs. J Transp Geogr. 2010;18(1):31-41.

28. Mavoa S, Witten K, McCreanor T, O'Sullivan D. GIS based destination accessibility via public transit and walking in Auckland. New Zealand Transp Geogr. 2012;20(1):15-22.

29. Zhao F, Chow LF, Li MT, Ubaka I, Gan A. Forecasting transit walk accessibility: regression model alternative to buffer method. Transp Res Rec. 1835:2003:34-41.

30. Syke. Model of Three Urban Fabrics (UF). 2013. Available from: https://www. syke.fi/en-US/Research_Development/Research_and_development projects/Projects/Model_of_Three_Urban_Fabrics_Urban_Fabrics. [cited 2020 Jan 16].

31. El-Geneidy AM, Tetreault P, Surprenant-Legault J. Pedestrian access to transit: identifying redundancies and gaps using a variable service area analysis; 2010

32. Burke M, Brown AL. Distances people walk for transport. Road Transp Res. 2007;16(3):16-29.

33. Sarker RI, Mailer M, Sikder SK. Walking to a public transport station: empirical evidence on willingness and acceptance in Munich, Germany. Smart Sustain Built Environ. 2019;.

34. Yang Y, Schumann M, Le S, Cheng S. Reliability and validity of a new accelerometer-based device for detecting physical activities and energy expenditure. PeerJ. 2018:2018(10):1-16.

35. Pesola AJ, Melin M, Vanhala A, Gao Y, Finni T. Does superPark make children less sedentary? How visiting a commercial indoor activity park affects 7 to 12 years old children's daily sitting and physical activity time. Int J Environ Res Public Health. 2018;15(8):1595.

36. Broberg A, Salminen S, Kyttä M. Physical environmental characteristics promoting independent and active transport to children 's meaningful places. Appl Geogr. 2013;38:43-52.

37. Kytta AM, Broberg AK, Kahila MH. Urban environment and children's active lifestyle: Softgis revealing children's behavioral patterns and meaningful places. Am J Heal Promot. 2012;26(5):e137-48.

38. Brown G, Kyttä M. Key issues and research priorities for public participation GIS (PPGIS): a synthesis based on empirical research. Appl Geogr. 2014;46: $126-36$

39. Hasanzadeh K, Laatikainen T, Kyttä M. A place-based model of local activity spaces: individual place exposure and characteristics. J Geogr Syst. 2018; 20(3):227-52.

40. Hillman M, Adams J, Whitelegg J. One false move: a study of children 's independent mobility. London: PSI Publishing; 1990

41. Lättman K, Olsson LE, Friman M. Development and test of the perceived accessibility scale (PAC) in public transport. J Transp Geogr. 2016:54:257-63.

42. Jago R, Fox KR, Page AS, Brockman R, Thompson JL. Development of scales to assess children's perceptions of friend and parental influences on physical activity. Int J Behav Nutr Phys Act. 2009;6:67. 
43. Geertz C. Thick Description: Toward an Interpretive Theory of Culture. Interpret Cult Sel essays. 1973:3-30.

44. Kullman K. Transitional geographies: making mobile children. Soc Cult Geogr. 2010;11(8):829-46.

45. Christensen P, Mikkelsen MR, Nielsen TAS, Harder H. Children, mobility, and space. J Mix Methods Res. 2011;5(3):227-46.

46. Goodman A, Jones A, Roberts H, Steinbach R, Green J. "We can all just get on a bus and go": rethinking independent mobility in the context of the universal provision of free bus travel to young Londoners. Mobilities. 2014; 9(2):275-93,

47. Barreira T, Schuna J, Tudor-Locke C, Chaput J, Church T, Fogelholm M, et al, Reliability of accelerometer-determined physical activity and sedentary behavior in school-aged children: a 12-country study. Int J Obes Suppl. 2015;5:29-35.

48. Reis RS, Salvo D, Ogilvie D, Lambert EV, Goenka S, Brownson RC. Scaling up physical activity interventions worldwide: stepping up to larger and smarter approaches to get people moving. Lancet. 2016;388(10051):1337-48.

49. Stokols D. Social ecology in the digital age: solving complex problems in a globalized world. London: Academic Press; 2018. p. 399.

50. Sallis J, Owen N. Theory EF-H behavior:, Research U, 2015 U. Ecological models of health behavior. Health Behavior and Health Education: Theory, Research \& Practice; 2002. p. 462-84.

51. Mehtala MAK, Saakslahti AK, Inkinen ME, Poskiparta MEH, Mehtälä MAK, Sääkslahti AK, et al. A socio-ecological approach to physical activity interventions in childcare: a systematic review. Int J Behav Nutr Phys Act. 2014;11(1):22.

52. Metcalf B, Henley W, Wilkin T. Effectiveness of intervention on physical activity of children: systematic review and meta-analysis of controlled trials with objectively measured outcomes (EarlyBird 54). BMJ. 2012;345(sep27 1): e5888.

53. Schoeppe S, Duncan MJ, Badland HM, Oliver M, Browne M. Associations between children's independent mobility and physical activity. BMC Public Health. 2014;14(1):1-9.

54. Standage M, Duda JL, Ntoumanis N. A model of contextual motivation in physical education: using constructs from self-determination and achievement goal theories to predict physical activity intentions. J Educ Psychol. 2003;95(1):97-110.

\section{Publisher's Note}

Springer Nature remains neutral with regard to jurisdictional claims in published maps and institutional affiliations.

Ready to submit your research? Choose BMC and benefit from:

- fast, convenient online submission

- thorough peer review by experienced researchers in your field

- rapid publication on acceptance

- support for research data, including large and complex data types

- gold Open Access which fosters wider collaboration and increased citations

- maximum visibility for your research: over $100 \mathrm{M}$ website views per year

At $\mathrm{BMC}$, research is always in progress.

Learn more biomedcentral.com/submissions 